\title{
Susuk or charm needle: a strange object detected on orthodontic diagnostic radiographs
}

\author{
Eby Varghese, ${ }_{1}^{1}$ Renu Sarah Samson, ${ }^{2}$ Sumanth Kumbargere Nagraj, ${ }_{1}^{3}$ \\ Pramod Redder Chandrappa ${ }^{4}$
}

\begin{abstract}
${ }^{1}$ Department of Paediatric Dentistry, Faculty of Dentistry, Melaka-Manipal Medical College, Bukit Baru, Melaka, Malaysia

${ }^{2}$ Faculty of Dentistry, Orthodontics, Melaka-Manipal Medical College, Bukit Baru, Melaka, Malaysia ${ }^{3}$ Faculty of Dentistry, Oral Medicine, Melaka Manipal Medical College, Melaka, Malaysia

${ }^{4}$ Department of Dentistry, Batterjee Medical College for Sciences and Technology, Jeddah, Makkah Province, Saudi Arabia
\end{abstract}

\section{Correspondence to}

Dr Eby Varghese,

varghese_eby@hotmail.com

EV and RSS contributed equally.

Accepted 19 October 2017

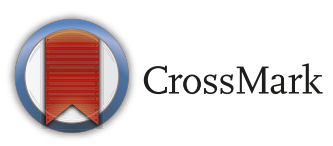

To cite: Varghese $E$, Samson RS, Nagraj SK, et al. BMJ Case Rep Published Online First: [please include Day Month Year] doi:10.1136/bcr-2017222497

\section{DESCRIPTION}

Uncommon and peculiar radiological findings resulting from cultural or religious beliefs and practices may be seen in individuals from certain parts of the world. With people migrating from these locations to other parts of the world, such findings often mystifies clinicians who may be unfamiliar with such traditions. ${ }^{1}$ Susuks or charm needles are one such cultural practices common in southeast Asia. These are metallic pins usually made of silver, gold or its alloys, measuring about $5-10 \mathrm{~mm}$ in length and $0.5 \mathrm{~mm}$ in diameter. It is claimed that susuk makes its wearers more beautiful, keeps them young, improves health, relieves pain and even help them attain an affluent career. A shaman would slowly rub the skin and gently insert the pins while doing some chanting. The procedure is painless with minimal or no bleeding and the pins remain in the soft tissues without causing any visible scarring or altered sensations. ${ }^{2}$ Orofacial region is the most common site for placement of susuks; however, it may be seen in other regions such as pubis, breasts, spine, limbs, etc. ${ }^{3}$

A female patient aged 41 years presented with a chief complaint of spacing and proclination of upper front teeth. She did not have any relevant medical or drug history. There were no signs of trauma or surgery evident extra-orally. Intraoral examination revealed full complement of teeth except 18, 28 and 38 (FDI notation), simple occlusal amalgam restorations on the occlusal surface of 36 and 46 as well as increased overjet, spaced upper and crowded lower anteriors. Since the patient's main concern was the malaligned teeth, she was referred to an orthodontist and diagnostic radiographs were taken.

The orthopantogram showed the absence of 18, 28 and 38; however, the 48 was present with mesioangular impaction. There was generalised

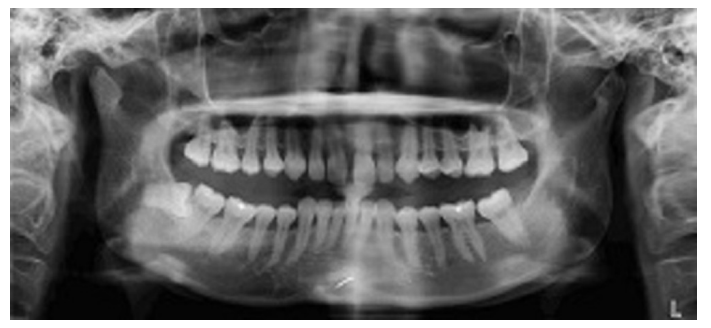

Figure 1 Orthopantomogram of the patient showing the well-defined, needle-like radiopaque object in the mandibular symphyseal region suggestive of a susuk.

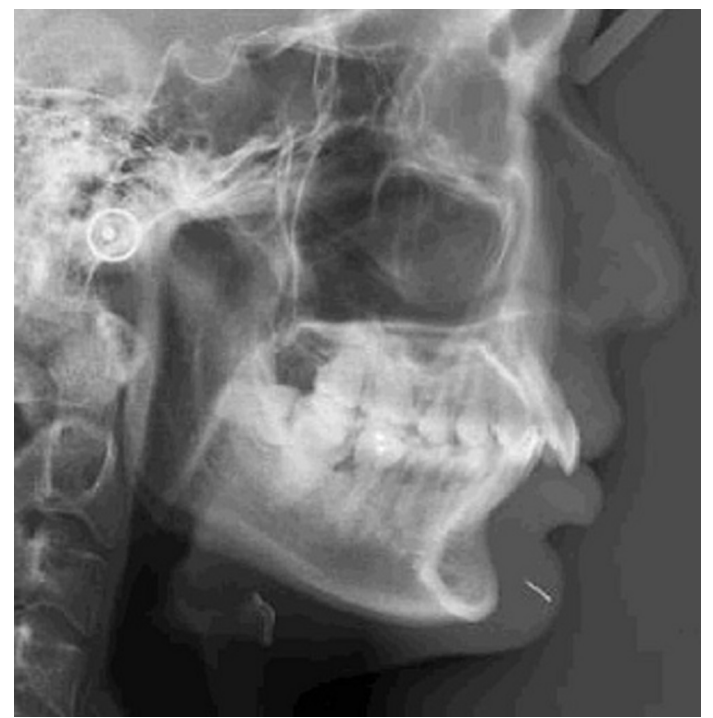

Figure 2 Lateral cephalogram of the patient showing the radiopaque object measuring about $7 \mathrm{~mm}$ in length and $<1 \mathrm{~mm}$ diameter, within the soft tissue of the chin.

interdental bone loss on both arches suggestive of periodontal disease. Interestingly, a strange well-defined needle-like object measuring about $7 \mathrm{~mm}$ in length and close to $1 \mathrm{~mm}$ in diameter was seen at the mandibular symphyseal region (figure 1). The object was also noticeable on the lateral cephalogram, embedded in the soft tissue of the chin (figure 2). Chin being a common site for injuries, a foreign body impacted into its soft tissue due to some form of trauma was suspected. Other differential diagnoses were possible dental procedures performed on the lower anterior teeth, mishaps during alternative therapy such as acupuncture or cultural practices like susuks. Since the patient's medical and dental history were unremarkable, she was questioned about the possibility of charm needles. On repeatedly asking, she agreed to have undergone placement of a susuk by a shaman around 10 years back. The susuk was placed with the claim that it would enhance her beauty and make her appealing to her husband. However, re-examination of the lower labial vestibule and chin did not reveal any signs of placement of susuk or scarring. Although the susuk could be localised radiographically, no attempt was made for its removal since it was non-palpable, the patient had remained asymptomatic and had preferred it to be left alone. 
- Susuks can be quite perplexing because it is not clinically visible or palpable, neither does it usually show any sign of its placement or scarring due to its presence. Moreover, patients often do not reveal undergoing such practices to the clinicians because of the restrictions given by the shaman or out of fear of being ridiculed due to the taboo associated with it. Therefore, most findings are purely incidental and are often revealed only on radiographs taken for medical or dental reasons. If the clinicians are unfamiliar with the existence of these practices, such radiographic findings often puts the clinician in a diagnostic dilemma and can mislead them to venture into unnecessary investigations and treatment.

- Susuks can lead to much obscurity in diagnostic procedures. First of all, they can easily be confused with pin-retained restorations, root canal fillings, broken instruments, acupuncture needles, etc. Second, ultrasound imaging to localise susuks may not be reliable due to echoreflections and the structures present beyond these metallic objects cannot be studied. Third, a study done previously showed that susuks do not exhibit ferromagnetism in 1.5 T machines and also suggested that similar properties may be expected even within machines of higher strength. ${ }^{3}$ However, such absence of ferromagnetism in machines above $1.5 \mathrm{~T}$ has not been proven yet. Therefore, it cannot be taken for granted that performing MRI in patients would be entirely safe since these metallic objects may carry the hazard of getting displaced into adjacent vital structures, especially if the magnetic strength of the machine is $>1.5 \mathrm{~T}$.

- In most cases, removal of the susuk is not possible due to unwillingness of patients in getting them removed due to either fear of surgical procedure or spiritual consequences and the presence of large number of susuks making its localisation and removal difficult. Other reasons include the asymptomatic nature of susuks that makes them remain unnoticed within the soft tissues for years as well as the difficulty in exactly localizing them which is especially challenging when they are numerous or thin and non-palpable within tissues. Localising the susuk in its exact position becomes even more challenging when there are multiple susuks or if they are thin and non-palpable within tissues. Added to these are the chances of hazards during MRI, radiographic artefacts, overlaps, secondary images, etc. On the other hand, susuks may carry the risk of dislodgement into vital structures, soft tissue infections, fibrosis of surrounding tissues, etc. They may corrode and get disintegrated, nevertheless attempts are made to remove them only if they cause infection or hinder surgical or radiation therapy of orofacial region. ${ }^{3}$

Contributors EV: manuscript writing and correspondence. RSS: manuscript and image editing. SKN: image interpretation and proof reading. PRC: proof reading.

Competing interests None declared.

Patient consent Obtained.

Provenance and peer review Not commissioned; externally peer reviewed.

C BMJ Publishing Group Ltd (unless otherwise stated in the text of the article) 2017. All rights reserved. No commercial use is permitted unless otherwise expressly granted.

\section{REFERENCES}

1 Shanmuhasuntharam P, Ghani SH. Susuks: charm needles in facial soft tissues. Br Dent J 1991;170:309-11.

2 Tandjung YR, Hong CP, Nambiar P, et al. Uncommon radiological findings: a case report. Int Dent J 2007;57:173-6.

3 Nambiar P, Ibrahim N, Tandjung YRM, et al. Susuks (charm needles) in the craniofacial region. Oral Radiol 2008;24:10-15.

Copyright 2017 BMJ Publishing Group. All rights reserved. For permission to reuse any of this content visit

http://group.bmj.com/group/rights-licensing/permissions.

BMJ Case Report Fellows may re-use this article for personal use and teaching without any further permission.

Become a Fellow of BMJ Case Reports today and you can:

- Submit as many cases as you like

- Enjoy fast sympathetic peer review and rapid publication of accepted articles

- Access all the published articles

- Re-use any of the published material for personal use and teaching without further permission

For information on Institutional Fellowships contact consortiasales@bmjgroup.com

Visit casereports.bmj.com for more articles like this and to become a Fellow 